fossils occur they are of varied kinds, whilst here nothing but oyster-shells have, so far, been found, and those apparently of one species. It is to be hoped that careful search for fossils will be made here.

The Reading Beds in the large pit agree in their composition with what had been found in the other sections, and it is clear, therefore, that hereabouts there is a fairly definite succession in the clays and sands, and that the blackish clay is the top bed of the series, serving, therefore, as an indication of the oncoming of the London Clay. But how far beyond that generalisation holds is another matter; it does not hold at Guildford or at Croydon. These questions and matters of detail may be left to the Geological Survey, which is now re-mapping the district.

The walk was continued to Sutton, where tea was taken.

Mr. A. L. Leach acted as Excursion Secretary.

\title{
REFERENCES.
}

Geological Survey Map, Sheet 3 (Drift). Iondon District.

New Ordnance Survey Map, Sheet $27 \mathrm{r}$.

1886. FrenCH, H. H.- "Excursion to Ewell and Epsom." Proc. Geol. Assoc., vol. xi, p. 532, price is.

I889. WhITAKER, W.-Geology of London and the Thames Valley." Vol. i, pp. 5, I09, I 26, 241, 489 .

I901. Stebbing, W. P. D.-"Excursion to Cheam, Ewell, and Epsom." Proc. Geol. Assoc., vol. xvii, pt. 4, price Is.

\section{REPORT OF AN EXCURSION TO RECULVERS.}

\section{Saturday, July zoth, I9I2.}

By W. Whitaker, B.A., F.R.S., F.G.S.,

\section{Director of the Excursion.}

Several members of the Selborne Society availed themselves of an invitation to join the excursion. The route taken followed the line of various previous excursions to the same place, and there is no need to go into stratigraphic details, which have been fully given elsewhere, and often.

Twenty-five members and friends took part, and the walk was from Herne Bay eastward, along the shore, so as to see the uprise of the successive beds of the Lower London Tertiaries, the whole of the cliff at first, and the higher part for a great way, being formed of London Clay, with some patches of gravel.

The leader pointed out the successive outcrops, and spoke of the great difference in the structure of the series here as compared with what is shown in the London district, and in the western and northern parts of the London Basin. He thought that no one not acquainted with the general facts, and seeing this Proc. Geol. Assoc., Vol. XXIII, Part 4, I9I2.] 
great East Kent section, would come to the conclusion that he was faced by the same divisions as occurred near London, any more than one would identify the beds seen in western Kent as equivalent to those of Reading and elsewhere. The peculiarities of the East Kent version of the Lower London Tertiaries are as follows :-

I. The series is wholly marine. Oldhaven Beds, Woolwich Beds and Thanet Beds yield marine fossils of much the same general character throughout.

2. The Oldhaven Beds consist of sand, except for a thin pebble-bed at the bottom, whereas in the western part of Kent and the eastern end of Surrey they consist chiefly of pebblebeds.

3. They rest pretty evenly on the beds below, from which, however, they are easily distinguished by the character of the sand, as well as by the pebble-bed at the base, the only bed of the kind in the whole of the Lower London Tertiaries here. In other parts they often lie very unevenly on the beds below.

4. The Woolwich Beds also consist wholly of sand, without either the shelly clays of the London district or the mottled clays that are of such general occurrence.

5. They have no definite bottom-bed, neither distinctive green sand nor pebbles. Consequently it is difficult to fix the plane of division with the Thanet Beds.

6. The Thanet Beds are different from the Thanet Sands to the west in that they are not a single mass of sand of like character throughout, but are more composite.

7. Their top member is a very pale greenish sand hardly to be distinguished (often practically indistinguishable) from the Woolwich Sand above. Indeed, anyone working in this district alone would not make a division between the two; it is only from a broader view, by which one can trace the incoming of a distinctive bottom-bed in the Woolwich Beds, that one is led to conclude that that division is represented here, with com. paratively few fossils.

8. The Thanet Beds are highly fossiliferous, instead of being generally unfossiliferous, as to the west.

9. The upper sand, which alone is in evidence at Reculvers, contains layers of large flat masses of sandstone.

10. Below this there comes a thick mass of a clayey or marly character, which is well shown in other parts of East Kent, and below that again other sand, the whole set of beds being much thicker than the Thanet Sand to the west, where probably the higher beds are absent.

Only some very small specimens of the peculiar selenite of the Oldhaven Beds were found, but enough to show the way in which the fine sand is caught up between the plates of the mineral (Plate $3^{6.8}$ ). 
Proc. Geol. Assoc., vol. XXIII.

PLATE 37 .

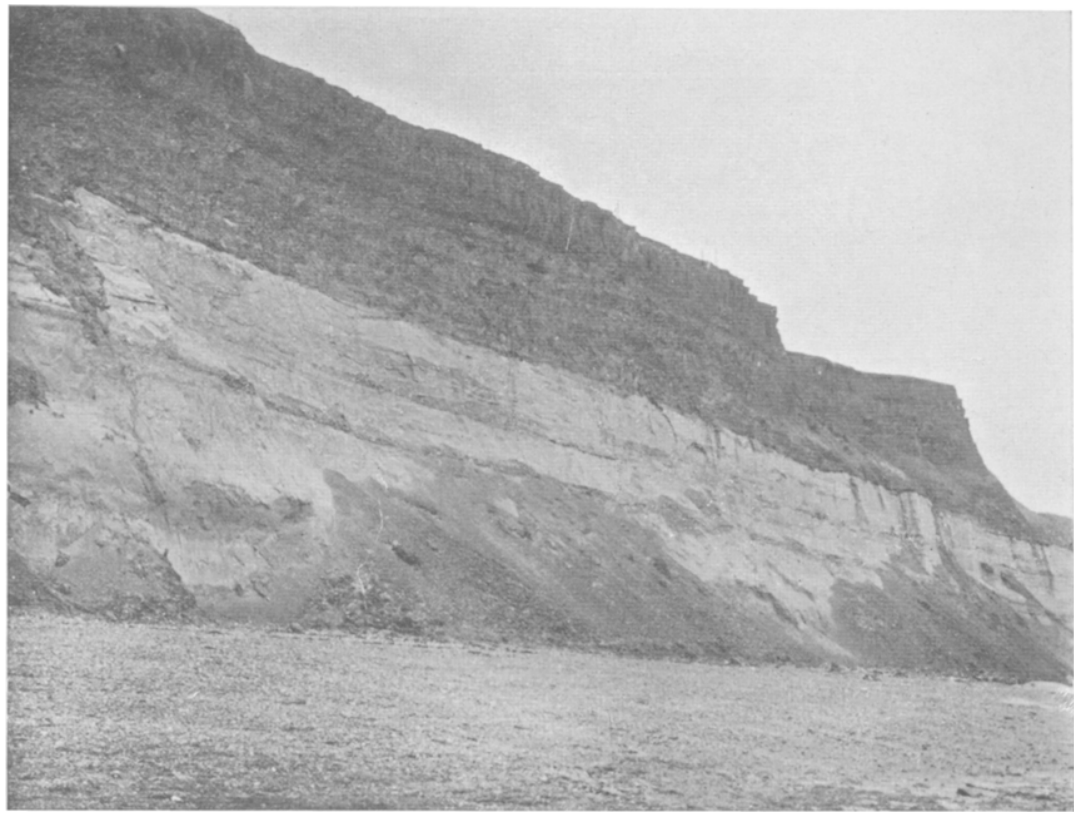

[Pjoto by T. W. Reader. A.-London Clay capping Otduaven Beds, westwakd of Oljuhaven GAP, HERNE BAY.

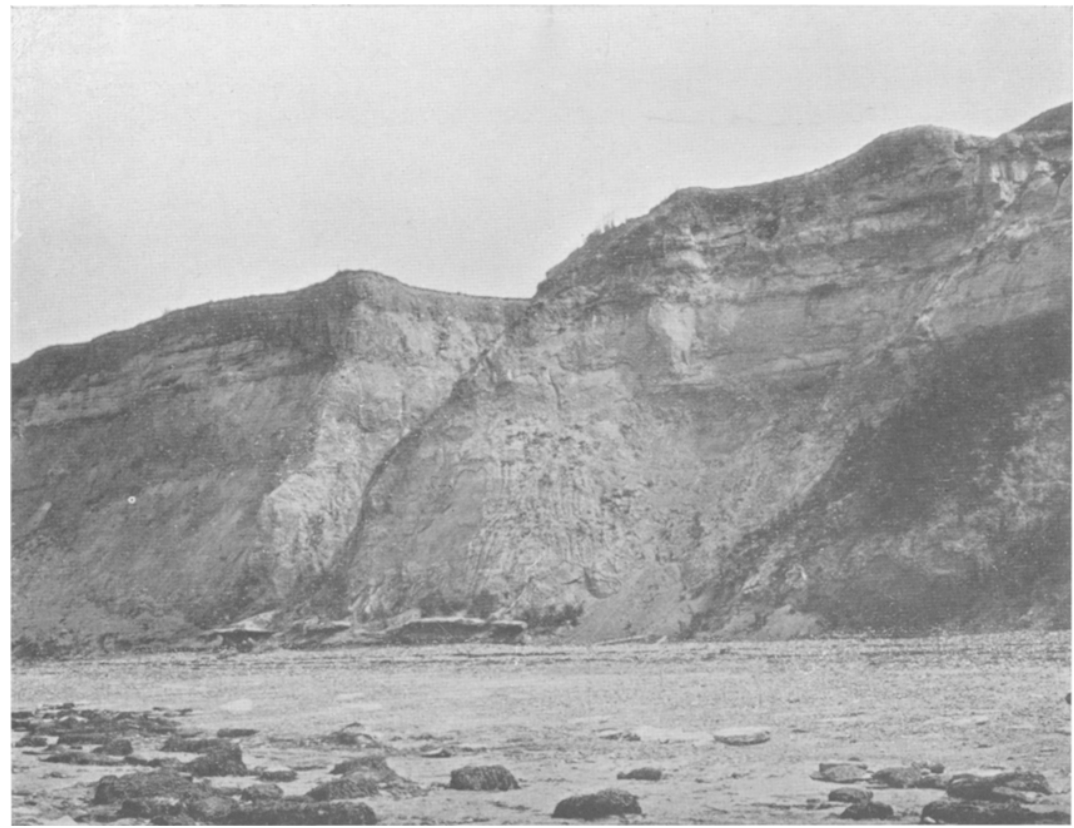

[Photo by T. W. Reader.

B. -London Clay, Oljhaven Beds and Woolwich Beds, eastward of Oldhaven Gar, Herne Bay. 
In the Corbula Bed at the bottom of the Woolwich Beds, many nests of $C$. regulbiensis were found, and some ill-defined nodules which looked as if phosphatic.

On reaching Reculvers the old church and the Roman wall were of course visited, and it was pointed out how the face of the country had changed since Roman times. Then there was a tidal channel dividing Thanet from the mainland, commanded on the north at Reculvers and on the east at Richborough, the Roman work being larger and more perfect at the latter place. Now the only water on the western side of Thanet is in the streams that pass through the green meadows of the marshland, whilst on the southern side of Thanet the tidal Stour flows in its confined channel through the marshes.

At Reculvers the marshland is protected from the sea by a strong bank, and what remains of the old Roman station is protected from loss by a stone slope, the twin towers of the church, alas! all that remains, being of value as a landmark.

The walk home was along the top of the cliff, and gave the chance of examining the implementiferous gravel of the higher part, of studying the loss of land along the coast, and of seeing something of the stream-erosion that has formed the pretty chine marked as Oldhaven Gap on the old map and as Bishopstone Gap on the new one. The enclosure of this spot was not approved of. 'Tea was taken at Herne Bay.

Plate 36.8 shows one of the groups of selenite crystals permeated with sand, so that the usual transparency is lost.

Plate 37.A shows the junction of the London Clay and the Oldhaven Beds, looking westward in the direction of the dip; the Woolwich Beds are also seen along the bottom part.

Plate $37 . \mathrm{B}$ is the section a little farther east so that lower beds are reached down to the Thanet Series. The Gap seen in the view is an illustration of the cutting through from springs at a high level.

Mr. Douglas Leighton acted as secretary.

\section{REFERENCES.}

Geological Survey Map, Sheet 3 (Drift).

New Ordnance Survey Map, Sheet 273.

I 850-54. PRESTWICH, J.- "On the Stuucture of the Strata between the London Clay and the Chalk." Part I, Quart. Fourn. Geol. Soc., vol. vi (1850); Part III, ibid., vol. viii (1852); Part II, ibid., vol. x (1854).

I860. WHITAKER, W.- "On the Lower London Tertiaries of Kent." Quart. Fourn. Geol. Soc., vol. xxii.

1872. - "The Geology of the London Basin." Mem.

I883. GARDNER, J. S.-." On the Lower Eocene Section between Reculvers and Herne Bay." Quart. Fourn. Geol. Soc., vol, xxxix. 